\title{
KARAKTERISTIK CUMI-CUMI ANALOG DARI SURIMI IKAN PATIN (Pangasius hypopthalmus) DENGAN MENGGUNAKAN BERBAGAI JENIS PATI
}

\section{Characteristics of Squid Analog from Catfish (Pangasius hypopthalmus) Surimi using Various Starches}

\author{
Theresia Dwi Suryaningrum ${ }^{1 *}$, Syamdidi ${ }^{1}$, Asmanah $^{2}$ dan Sakinah Haryati ${ }^{2}$ \\ ${ }^{1}$ Pusat Penelitian dan Pengembangan Daya Saing Produk dan Bioteknologi Kelautan dan Perikanan, \\ JI. KS Tubun Petamburan VI Slipi Jakarta Pusat, Indonesia \\ 2 Jurusan Perikanan Fak Pertanian Universitas Sultan Ageng Tirtayasa, Banten \\ * Korespondensi Penulis: tdwisuryaningrum@yahoo.com
}

Diterima: 28 Juni 2016; Disetujui: 30 Oktober 2016

\begin{abstract}
ABSTRAK
Cumi-cumi analog merupakan produk olahan tiruan dari surimi yang memiliki tekstur elastis, warna putih dan rasa khas cumi-cumi. Penelitian pembuatan cumi-cumi analog dari surimi ikan patin (Pangasius hypopthalmus) dengan menggunakan berbagai jenis pati telah dilakukan. Penelitian ini dibagi menjadi 2 tahap, yaitu tahap 1 berupa optimasi formula cumi-cumi analog untuk mendapatkan tekstur dan warna seperti produk yang ditiru. Formulasi cumi-cumi analog di dasarkan pada formulasi kamaboko dengan perlakuan penambahan karaginan ( $1 \%$ dan $5 \%$ ), konjak $(1,5 \%$ dan $2 \%$ ) dan pewarna puth (cloudy) (1\% dan 2\%). Penelitian tahap ke 2 dilakukan untuk mempelajari pengaruh jenis pati yaitu tapioka, kentang dan sagu terhadap karakteristik cumi-cumi analog yang dihasilkan. Pengamatan dilakukan terhadap nilai gizi, sifat fisik dan sensori cumi-cumi analog yang dihasilkan. Hasil penelitian menunjukkan penggunaan kombinasi karaginan $1 \%$, konjak $1,5 \%$ dan pewarna putih $2 \%$ menghasilkan tekstur produk yang elastisitas dan warnanya mendekati produk yang ditiru. Penggunaan berbagai jenis pati tidak berpengaruh terhadap nilai gizi dan $\mathrm{pH}$, namun berpengaruh nyata terhadap sifat fisik cumi-cumi analog yang dihasilkan. Cumi-cumi analog yang diolah dengan pati sagu menghasilkan tingkat kekerasan dan elastisitas paling tinggi, namun derajat putih paling rendah dibandingkan dengan tepung lainnya. Sedangkan cumi-cumi analog yang diolah dengan pati kentang menghasilkan kekerasan, elastisitas dan daya menahan air yang paling rendah dibandingkan dengan perlakuan lainnya. Uji sensori menunjukkan bahwa cumi-cumi analog yang diolah dengan menggunakan pati tapioka menghasilkan warna, rasa dan tekstur yang lebih disukai panelis dibandingkan dengan tepung lainnya. Sedangkan cumi-cumi analog yang diolah dengan pati kentang menghasilkan kenampakan dan bau yang lebih disukai panelis, namun mempunyai tekstur dengan nilai kesukaan yang paling rendah.
\end{abstract}

KATAKUNCI: surimi, cumi-cumi analog, ikan patin, Pangasius hypopthalmus, pati

\section{ABSTRACT}

Squid analog is a product processed from surimi, which has elastic texture, white colour and specific of squid taste. Research on processing of analog squid from catfish (Pangasius hypopthalmus) surimi using various types of starch has been performed. This research was divided into two steps; first step was optimization of squid analog formula to obtain desired elastisity and colour similar to the natural products. Formulation of squid analog was performed using kamaboko formula with the addition of carrageenan (1\% and $5 \%)$, konjac (1,5\% and $2 \%)$ and whitening agent (1\% and $2 \%)$. The second step was done to investigate the effects of various starches namely tapioca, potato and sago starch to the final product. Squid analogs were evaluated for their proximate composition, physical characteristics and sensory properties. The results showed that the use of carageenan of $1 \%$, konjac of $1,5 \%$ and whitening agent of $2 \%$ produced desired products which has similar elasticity and colour to natural squid. However, using various types of starch did not affect to the nutritional value and $\mathrm{pH}$, but they affected significantly the physical parameters of squid analog. Squid analog added with sago starch resulted in the highest hardness and elasticity but had a lower whiteness compared to tapioca and sago starch. Analog squid added with potato starch had the lowest hardness, elasticity and water holding capacity compared to other starches. The sensory evaluation showed that the addition of tapioca starch increased the acceptance level for attribute of colur, taste and texture. In other hand, the addition of potato starch increased the acceptance level for attribute of appearance and odor but not for the texture.

Keywords : surimi, squid analog, catfish, Pangasius hypopthalmus, starch 


\section{PENDAHULUAN}

Surimi merupakan konsentrat protein miofibril, yang diolah dari ikan lumat yang telah dicuci dengan air dingin berulang-ulang untuk menghilangkan protein sarkoplasmik, dan ditambah krioprotektan untuk dapat mempertahankan sifat fungsional protein miofibril selama penyimpanan beku (Rawdkuen, Sai, Khamson, Chaijan \& Benjakul, 2009). Konsentrat protein miofibril mempunyai sifat fungsional penting dalam proses pembentukan gel dan daya menahan air pada surimi. Berdasarkan sifat gelnya yang unik, surimi dapat diolah menjadi produk yang inovatif seperti crabstick, udang analog, chikuwa, sosis, burger dan produk berbasis surimi lainnya. Produk analog yang pertama kali dibuat dari surimi adalah crabstick, yang menjadi populer pada tahun 1970an dengan mencampur surimi, bahan pengisi, pembentuk tekstur, flavour dan pewarna (Romanowski, 2008). Saat ini hampir 35\% dari produk surimi dunia diolah menjadi crabstick terutama di Amerika dan Eropa ( Hur, Cho, Hun, Park \& Kim, 2011). Produk sejenis yang diolah dari surimi adalah scallop dan udang analog yang mempunyai karakteristik bentuk, kenampakan, warna dan flavour yang mirip aslinya (Sonu, 2002). Penelitian aneka produk olahan dari surimi telah dilakukan antara lain pada pembuatan analog udang (Punyabanth, 1996; Suwandi, Karmila \& Nurjanah, 1997), bakso cumi (Fernandez \& Mabeza, 1996), crabstick (Hur et al., 2011), spring rool (Okereke, 2011). Salah satu produk berbasis surimi yang belum banyak tersedia di pasaran adalah cumi-cumi analog. Cumi-cumi merupakan produk hasil perikanan yang banyak digemari masyarakat karena rasa dan teksturnya yang spesifik.

Dalam pembuatan cumi-cumi analog, produk yang dihasilkan harus mempunyai tekstur dengan elasitisitas yang tinggi, warna produk yang putih serta rasa khas cumi-cumi. Untuk mendapatkan tekstur dengan elastisitas yang tinggi, diperlukan formulasi antara surimi dengan tepung atau pati sebagai bahan pengisi, penambahan hidrokoloid dan bahan tambahan lainnya, seperti fosfat, putih telur dan emulsifier sehingga diperoleh produk yang kenampakan, warna, rasa dan teksturnya dapat mendekati produk yang ditiru (Saha \& Bhattacharyo, 2010). Penambahan pati, selain dimaksudkan untuk memperbaiki tekstur dan menghasilkan stabilitas matrik gel surimi juga dimaksudkan untuk meningkatkan daya menahan air serta sifat sensori dan nilai ekonomi produk yang dihasilkan (Lee, Wu \& Okada, 1997; Rasco \& Bledsoe, 2006). Berbagai jenis pati dapat digunakan untuk pembuatan produk analog, namun demikian pati tapioka merupakan bahan pengisi yang paling banyak digunakan karena mengandung amilopektin tinggi $(83 \%)$ sehingga dapat membentuk gel yang lentur dan kohesive (Zhang et al., 2012). Bahan pengisi lain yang dapat digunakan adalah pati kentang karena ukuran granulanya yang lebih besar dibandingkan dengan jenis pati lainnya. Karena ukuran granula yang lebih besar tersebut, pati kentang dapat mengikat air lebih banyak dan dapat menghasilkan gel yang elastis (Lee et al., 1997). Demikian juga pati sagu aren (Arenga pinnata) yang mempunyai kandungan amilopektin yang cukup tinggi $(75,92 \%)$, sehingga dapat membentuk gel yang elastis (Chalid \& Kusumawardani, 2010).

Untuk mendapatkan tekstur dengan gel yang mempunyai elastisitas tinggi beberapa jenis hidrokoloid dapat digunakan antara lain adalah karaginan, konjak, alginat dan curdland (Park, 2005). Menurut Morris (1998), konjak dan karaginan yang ditambahkan ke dalam surimi akan berinteraksi secara sinergis untuk menghasilkan gel yang lebih elastis. Penambahan karaginan dan konjak akan mendorong pembentukan jaringan tiga dimensi serta dapat meningkatkan kemampuan pembentukan gel dan dapat mengurangi kerapuhan produk olahan surimi yang dihasilkan (Xiong et al., 2009). Karaginan dan konjak merupakan kombinasi hidrokoloid yang paling cocok untuk protein ikan karena selain tidak berpengaruh terhadap warna produk juga dapat memperbaiki tekstur produk yang dihasilkan (Ramirez, Uresti, Velazques \& Vasques, 2011). Konjak merupakan hidrokoloid yang apabila dipanaskan dalam suasana basa akan membentuk gel yang kuat, elastis, dan stabil terhadap panas (Oteroa, Borderias \& Tovar, 2010).

Penelitian mengenai produk analog dari surimi telah dilakukan terhadap bakso cumi-cumi yang terbuat dari surimi yang diformulasikan dengan pati kentang $7 \%$ (Fernandez \& Mabeza, 1996). Pengolahan analog udang dari ikan nila dengan menggunakan karaginan $1 \%$, putih telur $5 \%$ dan pati tapioka $5 \%$, menghasilkan produk tiruan yang mendekati karakteristik tekstur udang jerbung yang dikukus dengan nilai kekerasan dan elastisitas masing-masing sebesar $6,46 \mathrm{~kg} / \mathrm{mm}$ dan 0,81\% (Suwandi et al., 1997). Menurut Park (2005) dalam industri surimi pati yang digunakan berkisar antara $4-12 \%$, namun kekuatan gel akan menurun jika pati yang digunakan lebih besar dari $20 \%$. Hasil penelitian pengolahan analog udang dengan menggunakan pati kentang sebanyak $7 \%$ diperoleh produk dengan nilai organoleptik yang cukup baik yaitu 0,82 dibandingkan dengan produk ideal yang nilainya 1 (Punyabanth, 1996).

Warna putih yang mirip cumi-cumi dapat diperoleh dengan menambahkan tepung pewarna putih (dipasaran sering disebut sebagai cloudy). Tepung pewarna putih merupakan busa hasil samping industri 
minyak kelapa sawit yang dikeringkan dan ditepungkan. Produk ini banyak digunakan dalam industri jelly yang menghendaki warna putih seperti putih telur (Alfian, Komunikasi pribadi, Februari 2013). Dalam penelitian ini dipelajari formulasi pembuatan cumi-cumi analog yang berbentuk ring (calamary). Formulasi pembuatan cumi-cumi analog didasarkan pada pembuatan kamaboko hasil penelitian Suryaningrum dan Ikasari (2010) yang dimodifikasi dengan penambahan hidrokoloid untuk meningkatkan tekstur gel yang lebih elastis dengan menambahkan karaginan dan konjak. Untuk meningkatkan warna putih ditambahkan tepung pewarna putih. Dari formulasi yang diperoleh kemudian dipelajari penggunaan berbagai jenis pati (tapioka, kentang, sagu) sebagai bahan pengisi terhadap karakteristik, sifat mutu, fisik dan sensori cumi-cumi analog.

\section{BAHAN DAN METODE}

\section{Bahan}

Bahan utama yang digunakan dalam penelitian ini adalah surimi ikan patin (Pangasius hypopthalmus) yang diolah dengan menggunakan krioprotektan trehalose $8 \%$ berdasarkan hasil penelitian Suryaningrum et al. (2013). Bahan tambahan untuk pembuatan cumi-cumi analog adalah pati tapioka, pati sagu aren, pati kentang, karaginan, konjak, penyedap rasa, gula, tepung pewarna putih (pembentuk warna putih), fosfat, putih telur, emulsifier dan flavour cumicumi.

\section{Metode}

Optimasi formula cumi-cumi analog: tahapan ini merupakan tahap pertama penelitian untuk mendapatkan formulasi yang menghasilkan tekstur dengan karakteristik seperti cumi-cumi. Formulasi cumi-cumi analog didasarkan pada pembuatan kamaboko hasil penelitian Suryaningrum dan Ikasari (2010) yang dimodifikasi. Modifikasi dilakukan untuk mendapatkan gel yang elastis dengan penambahan karaginan $1 \%$ dan 5\% (Ramirez et al., 2011) tepung konjak 1,5\% dan $2 \%$ (Xiong et al., 2009) serta perwarna putih $1 \%$ dan $2 \%$ (Alfian, komunikasi pribadi, Februari 2013) dari berat surimi yang digunakan. Penambahan tepung pewarna putih dimaksudkan untuk mendapatkan warna putih seperti putih telur. Formulasi yang digunakan adalah surimi, garam $2 \%$, tapioka $4 \%$, gula $3 \%$, putih telur $5 \%$, monosodium glutamat (MSG) $0,5 \%$, emulsifier $0,5 \%$ dan air es $10 \%$ yang didasarkan pada berat surimi yang digunakan.

Pembuatan cumi-cumi analog dilakukan sebagai berikut. Sebanyak $500 \mathrm{~g}$ surimi diaduk dengan garam $2 \%$ selama 2 menit dengan menggunakan mesin potator sehingga membentuk gel yang kenyal.
Karaginan (1\% \& 5\%) dicampur dengan konjak (1,5\% \& $2 \%$ ) sehingga diperoleh 4 campuran karaginan dan konjak. Campuran karaginan dan konjak dimasukkan sedikit demi sedikit ke dalam adonan surimi sambil diaduk sehingga tercampur secara homogen. Ke dalam adonan dimasukkan gula (3\%), putih telur (5\%), emulsifier $(0,5 \%)$ dan MSG (0,5\%), flavour $(1 \%)$, tepung pewarna putih (1\% \& $2 \%)$ dan pati tapioka $(4 \%)$ sehingga membentuk adonan yang kenyal. Emulsifier dibuat dari konsentrat protein kedelai, minyak, dan air dengan perbandingan 1:4:9 yang dihomogenisasi sehingga menjadi kental. Untuk menjaga suhu adonan tetap dingin ditambahkan air es $(10 \%)$.

Adonan dibuat lembaran dengan ketebalan $0,5 \mathrm{~cm}$, lebar $8 \mathrm{~cm}$ panjang $20 \mathrm{~cm}$ kemudian dililitkan pada batang kayu yang berbentuk bulat dengan diameter 1 $\mathrm{cm}$. Adonan yang sudah menempel pada kayu kemudian dibungkus lembaran aluminium tipis dan dikukus selama 10 menit sehingga membentuk gel kamaboko. Gel kemudian dikeluarkan dari kayu dan dipotong-potong dengan lebar $0,8 \mathrm{~cm}$ sehingga diperoleh cumi-cumi analog yang berbentuk ring. Produk kemudian dikukus kering selama 15 menit dengan memasukkannya ke dalam kantong plastik, sehingga produk tidak basah oleh uap air. Produk yang diperoleh diamati sifat sensori dengan mengamati elastisitas tekstur, warna serta kehalusan produk secara deskriptif. Formulasi yang menghasilkan produk terbaik digunakan dalam penelitian tahap kedua. Diagram alir pengolahan cumi-cumi analog dapat dilihat pada Gambar 1.

Perlakuan: Formulasi terbaik yang diperoleh pada tahap pertama kemudian diberi perlakuan jenis pati yaitu pati tapioka, pati kentang, dan pati sagu aren dengan konsentrasi masing masing sebesar $4 \%$. Efek penambahan jenis pati tersebut kemudian diamati karakaterisitiknya terhadap cumi-cumi analog yang dihasilkan. Pengamatan cumi-cumi analog dilakukan terhadap nilai gizi cumi-cumi yang meliputi kadar air, kadar abu, kadar protein, dan kadar lemak dengan menggunakan SNI 2006 (BSN, 2006), pH dengan dengan menggunakan pH meter (Yunizal et al., 1998) serta water holding capacity (WHC) dengan menggunakan metode Xiong et al. (2009). Uji fisik terhadap sifat tekstur dilakukan dengan menggunakan SNI 01-2694.1-2006 (BSN, 2006) dan pengukuran dilakukan dengan menggunakan texture analyzer TAXT. Derajat putih diukur dengan menggunakan colour flok (Park, 2005). Uji organoleptik diamati terhadap tingkat kesukaan dengan menggunakan uji mutu hedonik skala 1-7 (SNI 01-2346-2006) (BSN, 2006).

Percobaan dilakukan dengan menggunakan rancangan acak lengkap satu faktor yaitu perbedaan 


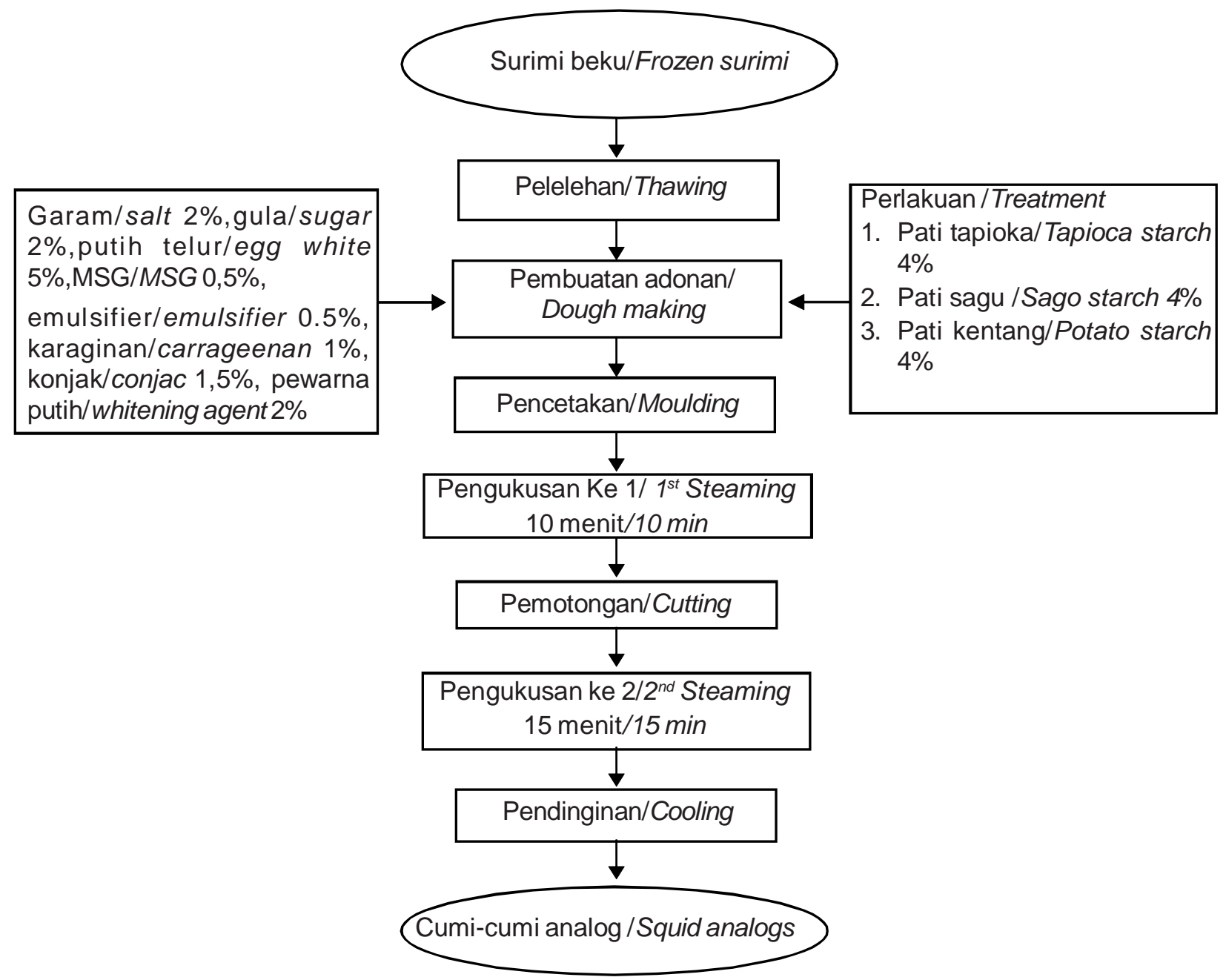

Gambar 1. Diagram alir pembuatan cumi-cumi analog

Figure 1. Flow chart processing of squid analogs

jenis pati dengan 3 kali ulangan. Faktor yang diberikan pada perbedaan jenis pati yaitu tapioka, kentang dan sagu. Data dianalisis dengan menggunakan program SPSS 16. Respon yang diukur meliputi analisis proksimat (kadar air, kadar abu, kadar protein, kadar lemak dan $\mathrm{pH}$ ) dan uji fisik (kekerasan, elastisitas, derajat putih dan WHC) sedangkan uji sensori (kenampakan,warna, rasa, bau dan tekstur) dianalisis secara deskriptif.

\section{HASIL DAN PEMBAHASAN}

\section{Karakteristik Surimi Ikan Patin (Pangasius hypopthalmus)}

Hasil analisis surimi yang digunakan sebagai bahan baku menunjukkan kadar air surimi sedikit lebih tinggi $(76,34 \pm 0,85 \%)$, dibandingkan dengan kadar air surimi yang disyaratkan dalam perdagangan yaitu kadar airnya kurang dari 75\% (Lanier \& Lee, 1992).
Namun kadar air surimi masih dalam batas kadar air yang disyaratkan oleh SNI 01-2694-2006 yaitu 80$82 \%$. Besarnya kadar air pada surimi berpengaruh terhadap konsentrasi tepung yang ditambahkan. Menurut Sarker et al. (2012) untuk surimi yang mempunyai kadar air $86 \%$ minimum jumlah tepung yang ditambahkan adalah sebesar $10 \%$, namun semakin banyak tepung yang ditambahkan akan menghasilkan produk yang elastisitasnya berkurang. Kadar abu surimi ikan patin sebesar 0,53 $\pm 0,03 \%$, masih dalam kisaran persyaratan mutu SNI 01-26942006 yaitu maksimum $1 \%$. Kandungan abu yang tinggi akan menyebabkan menurunnya kelarutan protein miofibril yang membentuk jaringan 3 dimensi yang berpengaruh pada menurunnya kekuatan gel yang dihasilkan (Romanoswski, 2008). Rata-rata kadar protein surimi sebesar $14,49 \pm 0,24 \%$, kadar protein tersebut dapat memberikan sifat gel yang kuat sehingga cocok untuk dibuat produk analog. Menurut Rasco \& Bledsoe (2006), minimun kadar protein yang 
diperlukan adalah $11 \%$ untuk membentuk gel yang kuat. Kandungan lemak pada surimi ikan patin dalam penelitian ini cukup rendah yaitu $1,43 \%$. Kandungan lemak yang tinggi pada surimi akan berpengaruh terhadap menurunnya mutu surimi. Proses pemanasan akan menyebabkan terjadinya interaksi antara lemak yang teroksidasi dengan protein sehingga menyebabkan terjadinya denaturasi, polimerasi serta perubahan sifat fungsional surimi (Morukawa, Benjakul, Visessanguen \& Tanako, 2003). Nilai pH surimi sebesar 7,24 masih dalam batas yang dikehendaki karena aktivitas aktomiosin yang berperan dalam pembentukan gel relatif stabil pada kisaran $\mathrm{pH}$ 6- pH 8 (Suzuki, 1981). Menurut Rasco \& Bledsoe (2006) konsentrasi garam yang digunakan untuk mengekstraksi aktin dan miosin tergantung pada kondisi $\mathrm{pH}$. Pada $\mathrm{pH} \mathrm{7,} \mathrm{konsentrasi} \mathrm{garam} \mathrm{yang}$ diperlukan minimum adalah $2 \%$, kisaran garam yang dapat diterima oleh indera perasa yang tidak terlalu asin.

Surimi yang digunakan dalam penelitian mempunyai daya lipat $A A$, yang artinya tidak retak setelah dilipat menjadi 4 yang tergolong dalam mutu baik dan merupakan salah satu syarat dalam pembuatan produk analog. Derajat putih surimi yang digunakan untuk penelitian ini adalah $68,74 \%$ dengan warna putih kekuningan atau sedikit kurang putih jika dibandingkan dengan warna putih dari kertas yang nilainya $100 \%$. Warna putih kekuningan tersebut terjadi karena daging ikan patin siam pada umumnya berwarna kekuningan dengan indek warna kuning yang cukup tinggi ( ${ }^{*} \mathrm{~b}=19,40 \pm 0,66$ ) (Suryaningrum, Muljanah \& Tahapari, 2010). Warna putih kekuningan ini akan menyebabkan produk analog yang dibuat kurang putih. Oleh karena itu dalam penelitian ini ditambahkan tepung pewarna putih untuk memperoleh warna produk yang lebih putih.

\section{Formulasi Cumi-Cumi Analog}

Hasil uji sensori secara deskriptif cumi-cumi analog dengan menggunakan formulasi kamaboko dengan berbagai konsentrasi konjak, karaginan dan tepung pewarma putih dapat dilihat pada Tabel 1. Penambahan tepung karaginan dan konjak dimaksudkan untuk memperoleh tekstur yang mendekati elastisitas dengan cumi-cumi. Pada dasarnya konjak merupakan hidrokoloid yang tidak dapat membentuk gel tanpa adanya alkali (Sarker et al., 2012). Karaginan dan konjak dapat bekerja secara sinergis sehingga dapat mendorong pembentukan gel dari konjak melalui interaksi segregatif dari kedua polimer tersebut, sehingga dapat membentuk gel dengan tekstur yang lebih kuat dan elastis (Brenner, Tuvikene, Fang \& Matsukawa, 2015).

Tekstur cumi-cumi analog yang diolah dengan menggunakan kombinasi karaginan 5\% dan konjak dengan konsentrasi baik $1,5 \%$ dan $2 \%$ menghasilkan produk dengan gel yang sangat keras dan kurang elastis. Produk ini tidak sesuai dengan tekstur cumicumi yang dikehendaki yang bersifat kenyal dan elastis. Kappa-karaginan merupakan hidrokolloid yang memiliki gel yang bersifat keras, karena adanya gugus 3,6-anhydrogalaktosa yang kurang menyerap air (Necas \& Bartosikova, 2013). Semakin tinggi kosentrasi karaginan yang digunakan maka semakin keras gel yang terbentuk. Kombinasi karaginan 1\% dengan konjak $2 \%$ menghasilkan produk yang permukaannya pecah pecah dan kurang halus sehingga kurang sesuai dengan kenampakan cumicumi yang permukaannya halus dan licin. Tepung konjak bersifat larut air dan dapat menyerap air hingga $138-200 \%$ dari volumenya sendiri (Wang \& Johnson, 2011). Penyerapan air tersebut menyebabkan polimer dikelilingi oleh molekul air yang termobilisasi sehingga menyebabkan granula konjak membengkak (Li, Ruan \& Qing, 2009). Ketika dipanaskan akan terjadi proses gelatinisasi dan granula konjak yang membengkak tersebut akan mengembang cukup tinggi (Imaningsih, 2012) sehingga menyebabkan permukaan produk menjadi pecah. Formulasi karaginan 1\% dengan konjak $1,5 \%$ menghasilkan produk yang cukup kenyal dan elastis, dengan permukaan yang halus dan licin. Hasil ini sejalan dengan hasil penelitian Liu, Wang dan Ding, (2013), dimana penggunaan konjak dengan konsentrasi $1,5 \%$ merupakan konsentrasi yang optimum untuk memperbaiki sifat gel pada surimi yang bermutu rendah.

Penggunaan tepung pewarma putih 1\% menghasilkan warna produk yang kurang putih sebagaimana diharapkan untuk warna putih cumi-cumi rebus, yang berwarna putih telur atau putih susu. Sedangkan formulasi tepung pewarma putih sebesar $2 \%$ menghasilkan produk yang berwarna putih telur seperti yang diharapkan. Oleh karena dalam penelitian ini formulasi yang dipilih untuk digunakan pada penelitian selanjutnya adalah perlakuan yang terdiri dari surimi ikan patin, garam (2\%), karaginan (1\%), MSG $(0,5 \%)$, gula $(3 \%)$, emulsifier $(0,5 \%)$, pewarna putih $(2 \%)$, fospat $(0,5 \%)$, flavour $(1 \%)$, konjak $(1,5 \%)$, tepung $(4 \%)$, putih telur $(5 \%)$ dan air es $(10 \%)$. Persentase bahan didasarkan pada berat surimi yang digunakan. Formulasi terbaik dari penelitian ini dijadikan sebagai dasar formulasi pada penelitian selanjutnya dengan menggunakan pati tapioka, pati kentang dan pati sagu aren.

\section{Pengaruh Penggunaan Berbagai Jenis Pati terhadap Sifat Kimia Cumi-Cumi Analog}

Hasil analisis kimia terhadap proksimat dan $\mathrm{pH}$ cumi-cumi analog dapat dilihat pada Tabel 2. Hasil analisis statistik menunjukkan bahwa perlakuan 
Tabel 1. Deskripsi cumi-cumi analog dengan berbagai formulasi penambahan hidrokoloid Table 1. Description of squid analogs using various hidrocolloids

\begin{tabular}{|c|c|}
\hline $\begin{array}{l}\text { Formulasi/ } \\
\text { Formulation }\end{array}$ & $\begin{array}{l}\text { Deskripsi/ } \\
\text { Description }\end{array}$ \\
\hline$A$ & $\begin{array}{l}\text { Tekstur kenyal, elastis, permukaan merata, halus, warna kurang putih/Chewy texture, elastic, } \\
\text { evenly smooth surface, opaque colour }\end{array}$ \\
\hline B & $\begin{array}{l}\text { Tekstur kenyal, elastis, permukaan merata, halus, mengkilap, warna putih telur/Chewy } \\
\text { texture, elastic, evenly smooth surface, shining, egg white colour }\end{array}$ \\
\hline C & $\begin{array}{l}\text { Tekstur sangat kenyal, pecah pecah, permukaan tidak merata, warna kurang putih/Very } \\
\text { chewy texture, broken, uneven surface less white colour }\end{array}$ \\
\hline$D$ & $\begin{array}{l}\text { Tekstur sangat kenyal, pecah pecah, permukaan tidak merata, warna putih telur/Very chewy } \\
\text { texture, broken, unevenly smooth surface, egg white colour }\end{array}$ \\
\hline$E$ & $\begin{array}{l}\text { Tekstur sangat keras, tidak elastis, warna kurang putih/Very hard texture, unelastic, less egg } \\
\text { white colour }\end{array}$ \\
\hline$F$ & $\begin{array}{l}\text { Tekstur sangat keras, tidak elastis, warna putih telur/Very hard texture, unelastic, egg white } \\
\text { colour }\end{array}$ \\
\hline $\mathrm{G}$ & $\begin{array}{l}\text { Tekstur sangat keras, tidak elastis, pecah pecah, warna kurang putih/Very hard texture, } \\
\text { unelastic, broken, less egg white colour }\end{array}$ \\
\hline $\mathrm{H}$ & $\begin{array}{l}\text { Tekstur sangat keras, tidak elastis, pecah-pecah, warna putih telur/Very hard texture, } \\
\text { unelastic, broken, egg white colour }\end{array}$ \\
\hline
\end{tabular}

Keterangan/Note :

$\mathrm{A}=$ Karaginan $1 \%$, Konjak 1,5\%, pewarna putih $1 \%$ (1\% Carrageenan, 1.5\% konjac, 1\% whitening agent)

$\mathrm{B}=$ Karaginan $1 \%$, Konjak 1,5\%, pewarna putih $2 \%$ (1\% Carrageenan, 1.5\% konjac, 2\% whitening agent)

$\mathrm{C}=$ Karaginan $1 \%$, Konjak $2 \%$, pewarna putih $1 \%$ (1\% Carrageenan, 2\% konjac, 1\% whitening agent)

$\mathrm{D}=$ Karaginan $1 \%$, Konjak $2 \%$, pewarna putih $2 \%$ ( $1 \%$ Carrageenan, 2\% konjac, 2\% whitening agent)

penggunaan berbagai jenis pati yang diberikan tidak berpengaruh terhadap proksimat dan $\mathrm{pH}$ yang dihasilkan $(p>0,05)$.

Cumi-cumi analog yang dihasilkan mempunyai kadar air berkisar antara 69,93-71,09\% dan lemak 2,58-2,92\%. Kadar tersebut sedikit lebih tinggi bila dibandingkan dengan BSN (2014) untuk bakso ikan, yaitu maksimal $70 \%$ dan lemak $2 \%$. Kadar air cumicumi analog dapat dikaitkan dengan kadar air surimi yang digunakan sebagai bahan baku yaitu $76,34 \pm$ $0,85 \%$ serta penambahan air ke dalam adonan. Dalam penelitian ini kandungan protein cumi-cumi analog yang dihasilkan berkisar antara 11,89-12,26\%, sedikit menurun dibandingkan dengan kadar protein surimi

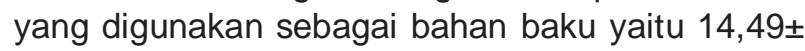
$0,24 \%$. Penurunan protein ini disebabkan adanya penambahan bahan pengisi yang kadar proteinnya rendah seperti pati, hidrokoloid, dan gula. Menurut Peraturan Menteri Kesehatan No. 75 Tahun 2013 (Anon., 2013) untuk memenuhi sebagai sumber kandungan gizi minimal harus $20 \%$ dari angka
$E=$ Karaginan $5 \%$, Konjak 1,5\%, pewarna putih 1\% (5\% Carrageenan, 1.5\% konjac, 1\% whitening agent) $\mathrm{F}=$ Karaginan $5 \%$, Konjak $1,5 \%$, pewarna putih $2 \%$ (5\% Carrageenan, 1.5\% konjac, 2\% whitening agent) $\mathrm{G}=$ Karaginan $5 \%$, Konjak $2 \%$, pewarna putih $1 \%$ (5\% Carrageenan, 2\% konjac, 1\% whitening agent) $\mathrm{H}=\mathrm{Karaginan} 5 \%$, Konjak $2 \%$, pewarna putih $2 \%$ (5\% Carrageenan, 2\% konjac, 2\% whitening agent)

kebutuhan gizi protein yang dianjurkan. Untuk orang dewasa angka kebutuhan gizi protein pria adalah 60 $\mathrm{g} / \mathrm{hari}$, sedangkan wanita $50 \mathrm{~g} / \mathrm{hari}$. Dua puluh persen $(20 \%)$ dari angka kebutuhan gizi protein orang dewasa yang dianjurkan adalah $12 \mathrm{~g}$. Oleh karena itu cumicumi analog yang dihasilkan dapat dikonsumsi sebagai sumber gizi protein apabila dikonsumsi $100 \mathrm{~g} / \mathrm{saji}$.

\section{Sifat Fisik Cumi-Cumi Analog}

Sifat fisik yang diharapkan pada cumi-cumi analog adalah tekstur dengan gel yang elastis serta warna produk yang putih. Hasil analisis sifat fisik cumi-cumi analog yang meliputi profil tekstur (uji kekerasan dan uji elastisitas), derajat putih dan WHC dapat dilihat pada Tabel 3.

Hasil uji statistik menunjukkan bahwa perlakuan yang diberikan berpengaruh nyata pada parameter yang diamati. Cumi-cumi analog yang diolah dengan penambahan pati sagu menghasilkan kekerasan yang paling tinggi dan berbeda nyata $(p<0,05)$ dengan 
Tabel 2. Proksimat cumi-cumi analog pada berbagai perlakuan penambahan pati Table 2. Proximate of squid analog using various starches

\begin{tabular}{lccc}
\hline \multicolumn{1}{c}{ Proksimat/Proximate } & \multicolumn{3}{c}{ Perlakuan/Treatment } \\
\cline { 2 - 4 } & $\begin{array}{c}\text { Penambahan pati } \\
\text { tapioka/Addition } \\
\text { of tapioca Strach }\end{array}$ & $\begin{array}{c}\text { Penambahan pati } \\
\text { kentang/Addition of } \\
\text { Potato strach }\end{array}$ & $\begin{array}{c}\text { Penambahan } \\
\text { sagu/Addition of } \\
\text { sago starch }\end{array}$ \\
\hline Kadar air/Moisture content (\%) & $71.09 \pm 0.91^{\mathrm{a}}$ & $71.01 \pm 0.89^{\mathrm{a}}$ & $69.93 \pm 1.00^{\mathrm{a}}$ \\
Kadar abu/Ash content (\%) & $2.68 \pm 0.19^{\mathrm{a}}$ & $2.73 \pm 0.04^{\mathrm{a}}$ & $2.79 \pm 0.07^{\mathrm{a}}$ \\
Kadar lemak/Fat content (\%) & $2.74 \pm 0.01^{\mathrm{a}}$ & $2.92 \pm 0.08^{\mathrm{a}}$ & $2.58 \pm 0.06^{\mathrm{a}}$ \\
Kadar protein /Protein content (\%) & $11.89 \pm 0.26^{\mathrm{a}}$ & $12.26 \pm 0.37^{\mathrm{a}}$ & $12.19 \pm 0.41^{\mathrm{a}}$ \\
$\mathrm{pH}$ & $7.50 \pm 0.06^{\mathrm{a}}$ & $7.30 \pm 0.04^{\mathrm{a}}$ & $7.50 \pm 0.01^{\mathrm{a}}$ \\
\hline
\end{tabular}

Keterangan/note :

a,b) Huruf yang sama pada kolom yang sama menunjukkan tidak berbeda nyata/a,b) The same letter in the same column indicates no significant difference.

perlakukan yang menggunakan pati tapioka dan pati kentang. Kekerasan gel yang dihasilkan dipengaruhi oleh sifat rheologi dan komposisi amilosa dan amilopektin pati yang digunakan. Pati yang mengandung amilopektin lebih banyak akan menghasilkan produk yang lebih mengembang sehingga memberikan tekstur yang lebih lunak, sedangkan pati yang mengandung amilosa tinggi akan memberikan efek keras pada produk yang dihasilkan (Li \& Yeh, 2003). Sagu mengandung amilosa sebesar $24,08 \%$, lebih tinggi dibandingkan dengan pati tapioka (17\%) dan pati kentang (21\%) (Niken \& Adipristiany, 2013). Oleh karena itu produk yang diolah dengan pati sagu yang kandungan amilosanya lebih tinggi dibandingkan tepung lainnya mempunyai tingkat kekerasan gel yang lebih tinggi. Kandungan amilosa pada pati sagu yang cukup tinggi ini menurut Copeland, Jaroslav, Salman, dan Tang (2009) akan menghasilkan gel yang keras karena pada proses gelatinisasi molekul amilosa terdifusi ke luar dari granula dan membentuk matriks 3 dimensi yang berpengaruh pada meningkatnya nilai kekerasan gel yang dihasilkan.

Dalam pembuatan cumi-cumi analog elastisitas yang tinggi merupakan sifat tekstur yang ditonjolkan. Elastisitas merupakan kemampuan laju suatu bahan yang diberi beban, kemudian kembali ke kondisi asal setelah gaya yang membebani ditiadakan (Deman, 1977). Hasil uji elastisitas terhadap cumi-cumi analog yang diolah dengan pati tapioka dan pati sagu menghasilkan tingkat elastisitas yang tidak berbeda nyata. Cumi-cumi analog yang diolah dengan pati kentang menghasilkan elastisitas yang lebih rendah dan berbeda nyata $(p<0,05)$ dengan perlakuan lainnya. Penggunaan pati kentang yang mempunyai granula berukuran yang lebih besar dibandingkan dengan jenis pati lainnya seharusnya dapat menghasilkan produk yang mempunyai sifat gel yang elastis karena dapat mengikat lebih banyak air (Lee et al., 1997). Namun dalam penelitian ini justru sebaliknya. Hal ini diduga karena kurangnya masa air di dalam adonan. Dalam

Tabel 3. Sifat fisik cumi-cumi analog dengan berbagai perlakuan penambahan pati

Table 3. Physcical properties of squid analog using various starches

\begin{tabular}{|c|c|c|c|c|}
\hline $\begin{array}{c}\text { Perlakuan } \\
\text { Penambahan/ } \\
\text { Treatment addition }\end{array}$ & $\begin{array}{c}\text { Kekerasan/ } \\
\text { Hardness } \\
\left(\mathrm{kg} / \mathrm{cm}^{2}\right)\end{array}$ & $\begin{array}{c}\text { Elastisitas/ } \\
\text { Elasticity } \\
(\%)\end{array}$ & $\begin{array}{c}\text { Derajat } \\
\text { putih/Whiteness } \\
\text { (\%) }\end{array}$ & $\begin{array}{c}\text { Daya menahan air } \\
\text { /Water holding capaciy } \\
\text { (\%) }\end{array}$ \\
\hline Pati tapioka & $1.12 \pm 0.16^{b}$ & $0.72 \pm 0.06^{a}$ & $85.82 \pm 0.05^{a}$ & $89.96 \pm 0.58^{b}$ \\
\hline Pati sagu & $1.84 \pm 0.77^{a}$ & $0.74 \pm 0.06^{a}$ & $83.52 \pm 0.15^{b}$ & $85.33 \pm 0.16^{b}$ \\
\hline Pati kentang & $1.25 \pm 0.40^{b}$ & $0.65 \pm 0.04^{b}$ & $85.10 \pm 0.62^{a}$ & $81.11 \pm 0.17^{a}$ \\
\hline
\end{tabular}

Keterangan/note :

a,b) Huruf yang sama pada kolom yang sama menunjukkan tidak berbeda nyata/a,b) The same letter in the same column indicates no significant difference. 
penelitian ini, untuk meningkatkan elastisitas gel yang dihasilkan di dalam formulasinya ditambahkan tepung karaginan dan konjak. Kedua senyawa tersebut bersifat menyerap banyak air, penambahan pati kentang yang juga bersifat menyerap air menyebabkan tidak semua molekulnya terdispersi di dalam air. Kondisi tersebut menyebabkan gelatinisasi pati kentang menjadi tidak sempurna, sehingga menyebabkan struktur gel cumi-cumi analog yang ditambah dengan pati kentang bersifat mudah patah dan kurang elastis. Di samping itu dalam pembentukan gel, protein juga menyerap banyak air sehingga menyisakan sedikit massa air yang dapat digunakan untuk proses gelatinisasi pati pada saat pemanasan (Zang et al., 2012). Pada saat pemanasan protein akan mengalami denaturasi terlebih dahulu sebelum proses gelatinisasi terjadi secara sempurna. Hal ini menyebabkan ketersediaan air untuk proses gelatinisasi menjadi terbatas karena air terperangkap dalam jaringan gel protein (Wu, Hamom \& Lanier, 1985). Menurut Imanningsih (2012) fenomena protein dan polisakarida yang berkompetisi untuk menyerap air yang terbatas dalam sistem akan berpengaruh terhadap sifat fungsional kompleks proteinpolisakarida. Saat protein mengalami denaturasi yang terjadi pada suhu $40-50^{\circ} \mathrm{C}$, air sudah digunakan untuk proses denaturasi tersebut sehingga sebelum suhu gelatinisasi yang seharusnya terjadi, yakni pada suhu $76^{\circ} \mathrm{C}$, sebagian air sudah digunakan sehingga proses gelatinisasi tidak sempurna dan akan berpengaruh terhadap kekuatan dan elastisitas gel yang dihasilkan.

Warna produk yang dihasilkan selain dipengaruhi oleh jenis pati yang digunakan, juga dipengaruhi oleh sifat dan bahan lain yang ditambahkan. Dari Tabel 3 terlihat bahwa cumi-cumi analog yang diolah dengan menggunakan pati sagu mempunyai derajat putih yang lebih rendah dan berbeda nyata $(p<0,05)$ dengan perlakuan lainnya. Pati sagu memiliki warna putih kecoklatan (putih krem) yang disebabkan oleh adanya material seperti sisa sisa serat, pertikel protein dan lemak, atau senyawa pembentuk emulsi seperti glyserol monostearat sehingga memberikan warna yang lebih gelap dan menghasilkan gel yang berwarna putih seperti tulang dan kurang jernih (Radley, 1976). Walaupun dalam penelitian ini sudah ditambahkan tepung pewarna putih sebesar $2 \%$, tetapi bahan tersebut tidak mampu menutupi warna krem dari pati sagu. Produk yang dihasilkan masih berwarna putih kusam sehingga cumi-cumi analog yang diolah dengan pati sagu memiliki nilai derajat putih yang rendah yaitu sebesar $83,52 \%$ jika dibandingkan dengan derajat putih cumi-cumi analog yang diolah dari pati tapioka $85,82 \%$ dan pati kentang $85,10 \%$.

Daya menahan air merupakan salah satu sifat fungsional protein yang dihasilkan dari interaksi matriks protein dengan air melalui ikatan hidrogen dan ikatan hidrofobik dalam pembentukan gel (Okada, 1992). Daya menahan air didefinisikan sebagai kemampuan matriks protein untuk menahan air ketika diberi tekanan (Ingadottir, 2004). Semakin banyak air yang dikeluarkan ketika diberi tekanan semakin rendah nilai daya menahan airnya. Penggunaan pati sebagai bahan pengisi selain untuk memperbaiki sifat tekstur juga bertujuan untuk membuat produk lebih ekonomis dengan meningkatkan daya menahan air tanpa mengurangi mutu tekstur yang dihasilkan. Hasil pengamatan menunjukkan bahwa daya menahan air cumi-cumi analog yang diolah dengan pati kentang sebesar $81,11 \pm 0,07 \%$, lebih rendah dan berbeda nyata $(p<0,05)$ dengan dengan pati tapioka dan pati sagu masing-masing sebesar $89,96 \pm 0,58 \%$ dan $85,33 \pm$ $0,16 \%$. Daya menahan air ini selain dipengaruhi pembentukan matrik gel yang baik, juga dipengaruhi oleh pH dan kekuatan ion. Daya menahan air semakin meningkat sejalan dengan meningkatnya $\mathrm{pH}$ produk yang dihasikan (Liu et al., 2010). Dalam penelitian ini $\mathrm{pH}$ adonan cumi-cumi analog yang diolah dengan pati kentang sebesar 7,3 lebih rendah dibandingkan dengan pati tapioka dan pati sagu (Tabel 3).

Di samping itu, rendahnya daya menahan air pada pati kentang disebabkan oleh pembentukan matrik gel yang kurang baik karena kurangnya massa air dalam adonan. Seperti telah dikemukakan sebelumnya, gel cumi-cumi analog yang diolah dengan pati kentang mengalami proses gelatinisasi yang tidak sempurna sehingga matrik gel yang terbentuk kurang baik dan gel yang dihasilkan kurang kuat. Ketika diberi tekanan maka cumi-cumi analog yang diolah dengan pati kentang tidak mampu menahan air di dalam produk. Semakin banyak air yang dikeluarkan akan menyebabkan nilai daya menahan airnya rendah.

\section{Sifat Sensori Cumi-Cumi Analog}

Uji sensori terhadap cumi-cumi analog dilakukan dengan uji mutu hedonik dengan skala 1-7 terhadap kenampakan, warna, bau, rasa dan tekstur (SNI 23462011).

\section{Kenampakan}

Kenampakan cumi-cumi analog yang diharapkan dalam penelitian ini adalah produk yang permukaannya halus dan licin serta mengkilap. Hasil penilaian terhadap kenampakan menunjukkan bahwa panelis memberikan nilai kesukaan paling tinggi terhadap kenampakan cumi-cumi analog yang diolah dengan menggunakan bahan pengisi pati kentang $(5,56)$, kemudian diikuti pati tapioka $(5,31)$ dan pati sagu $(5,00)$ (Gambar 3A). Cumi-cumi analog yang 
diolah dengan pati kentang menghasilkan produk yang permukaannya halus dan mengkilap. Penilaian kenampakan dapat dihubungkan dengan banyaknya air yang dapat diserap oleh granula pati. Semakin besar ukuran granula semakin banyak menyerap air sehingga menghasilkan produk yang lebih jernih dan mengkilap dan menghasilkan gel yang transparant dan lebih putih (Zang et al., 2012). Pati kentang mempunyai granula pati yang ukurannya paling besar (20-100 $\mu$ ) dibandingkan pati sagu (20-60 $\mu$ ) dan pati tapioka (5-35 $\mu$ ) (Winarno, 2004).

\section{Warna}

Warna produk cumi-cumi analog yang diharapkan adalah berwarna putih seperti putih telur. Panelis memberikan nilai warna tertinggi terhadap cumi-cumi analog yang diolah dengan menggunakan pati tapioka $(5,62)$ kemudian diikuti dengan cumi-cumi analog yang diolah dengan pati kentang $(5,50)$ dan pati sagu $(4,88)$ (Gambar 3 B). Penilaian warna cumi-cumi analog dipengaruhi oleh warna pati yang digunakan. Pati tapioka dan pati kentang diolah dari umbi sehingga mempunyai warna yang lebih putih dibandingkan dengan pati sagu yang diolah dari batang pohon. Penggunaan pati sagu sebagai bahan pengisi cumicumi analog kurang cocok karena menghasilkan warna yang tidak sesuai dengan produk yang ditiru.

\section{Rasa}

Panelis memberikan nilai kesukaan terhadap rasa cumi-cumi analog antara agak suka sampai suka. Nilai kesukaan paling tinggi diperoleh dari cumi-cumi analog yang diolah dengan menggunakan pati tapioka $(5,31)$, diikuti dengan pati kentang $(5,19)$ dan pati sagu $(5,0)$ (Gambar 3 C). Rasa pada cumi-cumi analog dipengaruhi oleh kadar garam, gula, fosfat serta MSG yang ditambahkan. Namun rasa yang spesifik diperoleh pada proses pemanasan, di mana gugus amin asam amino dari surimi akan bereaksi dengan gugus karbonil gula pereduksi dari pati, yang menghasilkan senyawa tertentu yang bertanggung jawab terhadap bau dan rasa (Bastos, Monaro, Siguemoto, \& Sefura, 2012).

\section{Bau}

Pada dasarnya surimi tidak berbau, oleh karena itu dalam pengolahan cumi-cumi analog sengaja ditambahkan flavour cumi-cumi sehingga produk olahan yang dihasilkan berbau seperti cumi-cumi. Panelis memberikan nilai bau tertinggi $(5,19)$ pada cumi-cumi analog yang diolah dengan pati kentang, diikuti dengan pati tapioka $(4,94)$ sedangkan nilai terendah diperoleh dari dari cumi-cumi analog yang diolah dengan menggunakan pati sagu $(4,75)$ (Gambar 3D). Aroma selain disebabkan oleh flavour yang ditambahkan juga dihasilkan karena pemasakan yang dapat meningkatkan karakteristik aroma yang dihasilkan. Dalam penelitian ini pemasakan dilakukan dengan menggunakan pengukusan $\left(95-98{ }^{\circ} \mathrm{C}\right)$ sehingga menghasilkan senyawa volatil hasil pemecahan protein dan flavouryang mudah menguap yang berpengaruh terhadap aroma cumi-cumi analog yang dihasilkan. Panelis cenderung lebih menyukai bau cumi-cumi analog yang menggunakan bahan pengisi pati kentang dibandingkan dengan pati lainnya. Suhu gelatinisasi mungkin dapat berperan dalam menahan flavour cumi-cumi yang ditambahkan dalam proses pengolahan selama pemanasan. Pati kentang mempunyai suhu gelatinisasi yang cukup rendah $\left(65-68{ }^{\circ} \mathrm{C}\right)$ dibandingkan dengan suhu gelatinisasi pati tapioka (suhu $70-74^{\circ} \mathrm{C}$ ) dan pati sagu $\left(88-90^{\circ} \mathrm{C}\right)($ Winarno, 2004). Suhu gelatinisasi yang rendah tersebut dapat melindungi flavour terhadap kerusakan panas. Pada saat terjadi gelatinisasi, flavour yang terlarut dalam air akan masuk ke dalam granula dalam sistem pati dan air (Yang \& Park, 1998). Pada pati kentang yang suhu gelatinisasinya lebih rendah, maka flavour cumi- cumi yang mudah menguap akan terlindungi lebih awal dibandingkan dengan pati lainnya.

\section{Tekstur}

Panelis lebih menyukai tekstur cumi-cumi analog yang diolah dengan menggunakan bahan pengisi pati tapioka $(5,31)$, sedangkan cumi- cumi analog yang diolah dengan pati kentang menghasilkan sifat tekstur yang paling tidak disukai $(4,44)$ (Gambar 3E). Pengaruh penambahan pati terhadap perubahan tekstur produk olahan surimi dapat dikaitkan dengan proses gelatinisasi pada pati kentang yang tidak sempurna. Pati kentang merupakan pati yang mempunyai kemampauan mengikat air cukup banyak, karena ukuran granulanya lebih besar dibandingkan dengan jenis pati lainnya (Lee et al., 1997). Pada formulasi karaginan dan konjak, protein akan menyerap banyak air terlebih dahulu, sebelum proses gelatinisasi terjadi. Pada proses pemanasan, proses gelatinisasi pati kentang menjadi tidak sempurna karena kurangnya masa air dalam adonan. Hal ini menyebabkan struktur gel surimi yang diolah dengan pati kentang yang kekurangan air menjadi sangat kaku dan mudah patah (Zang et al., 2012), sehingga kurang disukai oleh panelis. Sedangkan Tanikawa (1985) menginformasikan bahwa jika di dalam adonan jumlah air yang ditambahkan kurang, maka gel yang yang dihasilkan akan bersifat kaku dan mudah patah. Oleh karena itu cumi- cumi analog yang diolah dengan pati 



Keterangan/Note

$\mathrm{T}$ : Pati tapioka/Tapioca starch

$S$ : Pati sagu/ Sago starch

KT : Pati kentang/Potato starch

Gambar 3. Histogram uji mutu hedonik cumi- cumi analog pada berbagai perlakuan a) kenampakan, b) warna, c) rasa, d) bau, e) tekstur

Figure 3. Histogram quality hedonic scale of squids analog at various treatments a) appearance, b)colour, c) taste, d) odor, e) texture 
kentang mempunyai tekstur dengan nilai paling rendah.

\section{KESIMPULAN}

Modifikasi formulasi kamaboko dengan penambahan karaginan $1 \%$, konjak $1,5 \%$ dan pewarna putih $2 \%$ menghasilkan tekstur cumi-cumi analog yang elastisitas dan warnanya mendekati produk yang ditiru. Penggunaan berbagai jenis pati tidak berpengaruh terhadap nilai gizi dan $\mathrm{pH}$, namun berpengaruh terhadap sifat fisik cumi-cumi analog yang dihasilkan. Cumi-cumi analog yang diolah dengan pati sagu menghasilkan tingkat kekerasan dan elastisitas yang paling tinggi, namun derajat putih paling rendah dibandingkan dengan pati lainnya. Sedangkan cumi-cumi analog yang diolah dengan pati kentang menghasilkan kekerasan, elastisitas dan daya ikat air paling rendah dibandingkan dengan perlakuan lainnya.

Uji sensori cumi-cumi analog yang diolah dengan menggunakan pati tapioka menghasilkan warna, rasa dan tekstur yang lebih disukai oleh panelis dibandingkan dengan tepung lainnya. Sedangkan tepung kentang menghasilkan kenampakan dan bau yang lebih disukai panelis, namun mempunyai tekstur dengan nilai kesukaan yang paling rendah. Berdasarkan sifat fisik, sifat sensori, kemudahan mendapatkan dan harga pati yang digunakan, maka formulasi terbaik untuk pengolahan cumi-cumi analog adalah menggunakan pati tapioka.

\section{DAFTAR PUSTAKA}

Anonim. (2013). Pedomanan Menteri Kesehatan No. 75. Tentang Angka Kecukupan Gizi bagi Bangsa Indonesia

[BSN] Badan Standardisasi Nasional. (2006). SNI 01.2354 - 2006 Standar Nasional Indonesia. Cara Uji Kimia pada Produk Perikanan.

[BSN] Badan Standardisasi Nasional. (2006). SNI 01.2332 - 2006 Standar Nasional Indonesia. Cara Uji Mikrobiologi pada Produk Perikanan. Badan Standardisasi Nasional (BSN).

[BSN] Badan Standardisasi Nasional. (2006). SNI -012346-2006. Petunjuk Pengujian Organoleptik/ Sensori Badan Standardisasi Nasional (BSN).

[BSN] Badan Standardisasi Nasional. (2014). SNI 72662014. Bakso Ikan.

Bastos, D. M., Monaro, E., Siguemoto. E., \& Sefura, M. (2012). Maillard Reaction Product in Processed Food. Pros And Cons. In Food Industrial Processes. Methods and Equipment. Valdez B (Eds) Publisher in Tech, pp. 284-300.

Brenner, T., Tuvikene, R., Fang, Y., \& Matsukawa, S., (2015). Rheology of Higly Elastic lota-carrageenan/ kappa-carrageenan/xanthan/konjac glucomannan gels. Food Hydrocolloids, 44,136-144.

Chalid, A. \& Kusumawardani, G. (2010). Modifikasi tepung sagu menjadi maltodextrin menggunakan enzim á amylase. Skripsi. Jurusan Teknik Kimia Fakultas Teknik Universitas Diponegoro Semarang. $56 \mathrm{Hal}$.

Copeland, L., Jaroslav, B., Salman, H., \& Tang, M. C., (2009). Form and Fungsionality of Starch. Food Hydrocolloids, 23,1527-1534.

Deman, J. M. (1997). Kimia Makanan. Institut Teknologi Bandung. Bandung, 549.

Fernandez. D., \& Mabeza. L. (1996). Sensory quality attributes of crab analogue and squid balls from bighead carp (Aristichthys nobilis, R). Paper Seminar on Advances in fish processing technology in Southeast Asia in Realtion to quality management and workshop on the compilation og fish products in southeast Asia. Singapore. 28-2 Nov 1996. Organised by SEAFDEC, 26.

Hur, S., Cho, S., Hun, S. J., Park, J. W., \& Kim, D. S., (2011). Rice flour a fungtional ingredient for premium crabstick. Food Sci. Biotechnology, 20 (6),1639-1647.

Imanningsih, N. (2012). Profil gelatinisasi beberapa formulasi tepung-tepungan untuk pendugaan sifat pemasakan. Penelitian Gizi Makan, 35(1), 13-22.

Ingadottir, B. (2004). The Use Acid and Alkali Protei Solubilization and Preciptation Methods to Produce Functionla Protein Ingredients from Tilapia. Thesis. University of Florida. florida p 105.

Lee, C. M., Wu, M. C., \& Okada. M. 1997. Ingredient and Formulation Technology for Surimi Based Products. In Lanier, T. C., \& Lee, C. M. (Eds). Surimi Technology Pp : 273- 302. Marcel Dekker, Inc. NY. Basel. Hongkong.

Li, C. Y., \& Yeh, A. I. (2003) Effect of Starch properties on rheological characteristics and swelling meat complex. J. of Food Enginering. 57 (3), 287-294.

Li, L., Ruan, H., \& Qing, H. G. (2009). Study on swelling model and thermodynamic structure of native konjac glucomannan. Jounal of Zhejian University Sci., 10 (4), 273-279.

Lanier. T. C., \& Lee, C. M. (1992). Surimi Technology. Marcell Dekker, INC New York. ISBN 0-8247-8470-7

Liu, J., Wang, Z., \& Ding, Y. (2013). Optimization of adding konjac glucomannan to improve gel properties of low-quality surimi. Carbohydrate Polymers, 92 (2) 484-489.

Liu, R., Zhao, S. M., Liu, Y. M., Yang, H., Xiong, S. B., Xie, B. J., \& Qin, L. H. (2010). Effect of pH on the gel properties and secondary structure of fish myosin. Food Chemistry, 121, 196 -202.

Morris, V. J. (1998). Gelation of Polysaccharides. In SE Hill., D.A. Ledward and J.R. Mitchell (Eds). Functional Propersties of Food Macromolocules. $2^{\text {nd }}$ Edition, 143-226.

Morukawa. Y., Benjakul, S., Visessanguan, W., \& Tanako, M. (2003). Inhibitor effect of oxidised lipid on the thermal gelation of Alaska pollack (Theragra 
chalcogramma) surimi. Food Chemistry. 82, 455463.

Necas, L., \& Bartosikova, I. (2013). Carregeenan a Riview. Veterinami Medicina, 58, 187-205.

Niken, A., \& Adipristiany. D., (2013). Isolasi Amilosa dan Amylopektin dari pati kentang. Jurnal Teknologi Kimia dan Industri, 2(3), 57-62.

Okada, M. (1992). The History of Surimi and Surimi Based Product in Japan. In C.L. Tyre and M.L Chong (Eds) . Surimi Technology. New York. Marcel Dekker, Inc, 3-21.

Okereke, A . (2011). Sensory evaluation of fish spring roll produced from Tilapia and Cat fish. Continental Journal of Food Sci. \& Tecnol., 5(3), 12-16.

Oteroa, A. I., Borderias, J., \& Tovar, C. A. (2010). Use of Konjac glucomannan as additive to reinforce the gels from low-quality squid surimi. Journal of Food Enginering, 101, 281-288.

Park, J. W. (2005). Surimi and Surimi Seafood. $2^{\text {nd }}$ Edition. CRC Press. Florida USA.

Punyabanth, P. (1996). Production of value added product from surimi : Shrimp analogue. Master Thesis. Prince of Songkla University, 105.

Ramirez, J.A., Uresti, R.M., Velazques. G., \& Vazquez. (2011). Food hydrocolloids as additivees to improve the mechanical and functional properties of fish products; A riview. Food Hydrocolloids, 25,1842-1852.

Rasco, B \& Bledsoe. G. (2006). Surimi and Surimi Analog Products. In Hui . Y. H. CRC Taylor \& Francis (eds) Hanbook of Food Science, Technology and Enginering. Boca Raton, London, New York.

Rawdkuen, S., Sai, U. S., Khamsorn, S., Chaijan, M., \& Benjakul, S. (2009). Biochemical and gelling properties of Tilapia surimi and protein recovered using an acid alkaline process. Jurnal of Food Chemistry, 112, 112-119.

Romanowski, P. (2008). Imitation Crab Meat. Http://www. gale-edit.com/products/volumes/crab-meat.html

Radley, J. A. (1976). Industrial Uses od Strach and Its Derivatives. Applied Science Publ. Ltd. London, 268.

Saha, D., \& Bhattarcharya. (2010). Hydrocolloids as tickening and gelling agent in food: a critical review. J. Food Sci. Technol., 47(6), 587-597.

Sasaki, T., \& Matsuki, J. (1998). Effect of wheat strach structure on swelling power. Cereal Chemistry, 75(4), 525-529.

Sarker, M. Z. I., Elgadir, M. A., Fredosh, S., Akanda, M. J. H., Manap, M.,Y. A., \& Noda. T. (2012). Effect of some Biopolymers on the Rheological Behavior of Surimi Gel. Molocules, 17, 5733-5744.

Sonu, S. C. (2002). Surimi suplay, Demand and Market of Japan. NOAA-TM-NMFS-SWR-039. US Departement of Commerce National Oceanic and
Atmospheric Administration National Marine Fisheries Service Southwest Region. p 65.

Suryaningrum, T. D., \& Ikasari, D. (2010). Pengaruh Penambahan Tepung Tapioka Termodifikasi dan Putih Telur terhadap Kamaboko Surimi Ikan Patin (Pangasius hypopthalmus). Prosiding Seminar Nasional Perikanan 2010. Sekolah Tinggi Perikanan. 4-5 Desember 2010,p 11.

Suryaningrum, T. D., Muljanah, I., \& Tahapari, E. V. (2010) Profil sensori dan Nilai Gizi Beberapa Jenis Ikan Patin dan Hibrid Nasutus. Jurnal Pascapanen dan Bioteknologi Kelautan dan Perikanan, 5(2),153-164.

Suryaningrum, T. D., Peranginangin, R., Irianto, H. E., Syamdidi, Muljanah, I., \& Octavirini, H. (2013). Laporan Teknik Nilai Tambah Peningkatan Nilai Tambah dan Diversifikasi Produk Olahan Ikan Air Tawar. Balai Besar Penelitian dan Pengembangan Pengolahan Produk dan Bioteknologi Kelautan dan Perikanan, p 86.

Suwandi, R., Karmila, M., \& Nurjanah. (1997). Karakteristik daging udang tiruan dari ikan nila merah (Oreochromis sp). Bulletin Teknologi Hasil Perikanan, 3 (2), 59-66.

Suzuki, T. 1981. Fish and Krill Protein Prossecing Technology. Applied Sceince. Japan.

Tanikawa, E. (1985). Marine Products in Japan. Koseikha Koseikaku Co Ltd. Tokyo.

Winarno, F. G. (2004). Ilmu Pangan dan Gizi. PT Gramedia Pustaka Utama, p 86.

Wang, W., \& Johnson. A. (2011). Introduction to Konjac. Technical Artical. Cyber Colloid, p 3.

Wu, M. C., Hamann, D. D., \& Lanier, T. C. (1985). Thermal Transition of admixed starch -fish protein system during heating. J. of Food Science, 50(1), 20-25.

Xiong, G., Cheng, W., Ye, I., Du, L., Zhou, Lin, R., Geng, S., Chen, M., Corke, H., \& Cai, Y. Z. (2009). Effects konjac glucomannan on physicochemical properties of miofibrillar protein and surimi gel from grass carp (Ctenopharyngodon idella). J. Food Chemistry. 116, 413-418.

Yang, H., \& Park J. W. (1998). Effects of Stsrch properties angd thermal processing conditions on surimi- starch gels. Lebensm. Wiss. Technol., 31, 344-353.

Yunizal, Murtini, T., Dolaria, N., Purdiwoto, B., Abdulrokhim, \& Carkipan, 1998. Prosedur Analisis Kimiawi Ikan dan Produk Olahan Hasil Perikanan. Instalasi Penel. Perikanan Laut Slipi. Balai Penel. Perikanan Laut, Pusat Penelitian dan Pengembangan Perikanan Jakarta, p 100.

Zhang, F., Fang, L., Wang, C., Shi, L., Chang, T., Yang, H., \& Cui, M., (2012). Effect of straches on textural, rheological, and colour properties surimi-beef gels with microbial transglutaminase. Meat Science, 93, 533-537. 